\title{
The Substantiation of the Pre-Polymerization Heating Efficiency of the Dental Nanocomposite Material
}

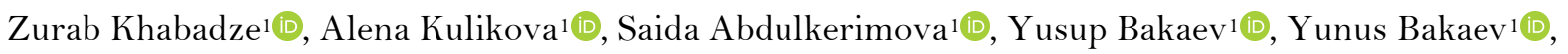

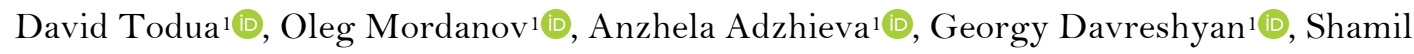 \\ Solimanov ${ }^{1}$, Shamil Nazhmudinov1(1)
}

${ }^{1}$ Medical Institute, Peoples' Friendship University of Russia, Moscow, Russia.

Author to whom correspondence should be addressed: Oleg Mordanov, Medical Institute, Peoples' Friendship University of Russia, Miklukho-Maklaya st., 6, Moscow, Russia.117198. Phone: +79123331533. E-mail: mordanov19@gmail.com.

Academic Editor: Alessandro Leite Cavalcanti

Received: 23 February 2020 / Accepted: 08 May 2020 / Published: 16 July 2020

How to cite this article: Khabadze Z, Kulikova A, Abdulkerimova S, Bakaev Y, Bakaev Y, Todua D, et al. The substantiation of the pre-polymerization heating efficiency of the dental nanocomposite material. Pesqui Bras Odontopediatria Clín Integr. 2020; 20:e0030. https://doi.org/10.1590/pboci.2020.139

\begin{abstract}
Objective: To evaluate the effect of pre-polymerization heating of nanocomposite filling materials on their strength properties within one manufacture group. Material and Methods: Two nanocomposite filling materials Enamel Plus HRi Universal Dentin ${ }^{\circledR}$ and Universal Enamel ${ }^{\circledR}$ were used. The linear thermal expansion coefficient (LTEC), Young's modulus and penetration depth were determined during the tests. Changes in the structure of materials were evaluated using electron scanning microscopy. Results: Dentin nanocomposite samples after pre-heating and polymerization have higher LTEC after $30^{\circ} \mathrm{C}$ compared to dentine nanocomposite untreated samples with statistically significance started at $62^{\circ} \mathrm{C}(\mathrm{p}<0.05)$ and higher temperature. Pre-polymerization heated samples had a statistically higher LTEC $(\mathrm{p}<0.05)$ at $57^{\circ} \mathrm{C}$. It was revealed that Young's modulus of the dentin nanocomposite samples after thermal processing at $55^{\circ} \mathrm{C}$ was higher in total after the first heating cycle by $15 \%$ compared to the untreated dentin nanocomposite samples $(\mathrm{p}<0.05)$. The volume of total porosity after pre-heating decreased to $5-7 \%(\mathrm{p}<0.05)$. Conclusion: The material that has undergone preliminary heat processing is significantly less deformed under load than the material that does not have thermal processing during the research was established and also has a denser structure.
\end{abstract}

Keywords: Dental Materials; Composite Resins; Materials Testing. 


\section{Introduction}

The changes in composite resin fillers have resulted in improvements in the physical, mechanical, and esthetic properties of these materials [1]. For example, nanosized fillers have been introduced to improve the mechanical properties of such resins [2]. The successful clinical handling and placement mainly depend on suitable pre-cure properties of composites [3]. Pre-cure handling properties, such as flowability, stickiness, ease of placement and adaptation to cavity walls affect product selection for clinical restoration [4,5]. As well, improving composite-to-tooth bond strength has been the objective of many recent dental researches [6].

Several studies have evaluated pre-polymerization heating of dental composite resins [7-9]. Preheating makes resin-based composites more fluid and easier to manipulate, without compromising their superior mechanical properties [10]. Enhanced flowability can be advantageous in achieving a better adaptation to the cavity walls [11-15].

The positive effect of pre-polymerization heating of the composite material has been noted in other studies. Some authors, as well, paid attention to the improvement of plasticity and fluidity of the filling material, which greatly facilitates the process of sealing [16]. Previous authors have noted that the reduction of the polymerization stress in the pre-heating of the composite material, which contributes to the improvement of the border between the tooth and the composite material [17,18]. Dionysopoulos et al. [19] found that pre-heating composites to $55^{\circ} \mathrm{C}$ increase their surface microhardness. A significant reduction in composite material degradation after exposure to temperature before polymerization was observed [20].

This study aimed to determine the effect of pre-polymerization heat processing of nanocomposite filling materials on their strength properties within one manufacture. The null hypotheses were: (1) the preheating of dental nanocomposites did not affect linear thermal expansion, and (2) the pre-heating of dental nanocomposites influence Young's Modulus after polymerization.

\section{Material and Methods}

\section{Study Design}

In this in vitro study, sixty testing specimens from the nanocomposite material were made of around shape with a diameter of $0.8 \mathrm{~mm}$ with Enamel Plus HRI Universal Enamel ${ }^{\circledR}$ and Enamel Plus HRI Universal Dentin $^{\circledR}$ (Micerium S.p.A., Avegno, Italy). All samples were divided into 4 groups: G1 - Enamel nanocomposite (Universal Enamel ${ }^{\circledR}$ ) without heat processing; G2 - Dentin nanocomposite (Universal Dentin ${ }^{\circledR}$ ) without heat processing; G3 - Enamel nanocomposite (Universal Enamel ${ }^{\circledR}$ ) after heat processing at $55^{\circ} \mathrm{C}$ and G4 - Dentin nanocomposite (Universal Dentin ${ }^{\circledR}$ ) after heat processing at $55^{\circ} \mathrm{C}$.

Two of the four groups were heated in a special oven to $55^{\circ} \mathrm{C}$ before polymerization with one heating cycle; the other two were tested without pre-heating. Polymerization was provided with the VALO Cordless Light Curing Unit (Ultradent Products Inc., South Jordan, UT, USA) with $13.1 \mathrm{~mm}$ tip external diameter, 9.6 $\mathrm{mm}$ tip internal diameter, $0.72 \mathrm{~cm}^{2}$ of tip area and $1169.4 \mathrm{~mW} / \mathrm{cm}^{2}$ of calculated irradiance. These settings are satisfied to deliver the same irradiance to the whole sample [21].

Testing and evaluation methods were provided with the following international standards [22-25]. The devices that were used for the measurements are described in Table 1.

The evaluation of coefficient of thermal linear expansion of the investigated materials was carried out in the temperature range from $-10^{\circ} \mathrm{C}$ to $+80^{\circ} \mathrm{C}$, with a heating rate of $1 \mathrm{~K} / \mathrm{min}$. The samples underwent several cycles of heating-cooling, after which we recorded coefficient of linear thermal expansion. 
Table 1. Technical characteristics of the devices used for the measurements.

\begin{tabular}{|c|c|c|c|c|}
\hline Devices & Serial Number & $\begin{array}{c}\text { Measurement } \\
\text { Range }\end{array}$ & $\begin{array}{c}\text { Tolerance, Measurement } \\
\text { Uncertainty }\end{array}$ & $\begin{array}{c}\text { Date of } \\
\text { Certification }\end{array}$ \\
\hline $\begin{array}{c}\text { Netzsch Dynamic Mechanical } \\
\text { Analyzer (DMA } 242 \mathrm{C} \text { ) }\end{array}$ & $160-3-148 \mathrm{G}$ & $(-160 \div 600)^{\circ} \mathrm{C}$ & $\pm 1^{\circ} \mathrm{C}$ & 27.10 .2017 \\
\hline Calliper 70-0,05 & $1 \mathrm{~B} 201782$ & $(0,03 \div 70) \mathrm{mm}$ & $\pm 0.03 \mathrm{~mm}$ & 07.06 .2017 \\
\hline
\end{tabular}

The coefficient of linear thermal expansion reflects the relative increment in the sample's length caused by an increase in its temperature by one degree. Thermometric analysis (TMA) is used for testing. The change in the size of the test sample with the help of TMA equipment is determined as a function of temperature while obtaining a TMA curve from which the coefficient of linear thermal expansion and the glass transition temperature are determined.

The differential coefficient of linear thermal expansion $\alpha, \mathrm{K}-1\left({ }^{\circ} \mathrm{C}-1\right)$ at $\mathrm{T}$ is calculated using the TMA curve according to the formula: $\boldsymbol{\alpha}=\mathbf{d L} / \mathbf{d T} \times \mathbf{1} / \mathbf{L}_{\mathbf{o}}$; where $\mathrm{L}$ : the length of the test sample at $\mathrm{t}, \mu \mathrm{m}$; T-test temperature, $\mathrm{K}\left({ }^{\circ} \mathrm{C}\right)$. Lo - the length of the test sample at $23^{\circ} \mathrm{C}, \mu \mathrm{m}$. The calculation of $\alpha$ is carried out with an accuracy of $1 \cdot 10^{-7} \mathrm{~K}^{-1}\left({ }^{\circ} \mathrm{C}^{-1}\right)$ separately for each test sample. As a result of the test, take the arithmetic mean value $\alpha$ for individual samples, rounded to $1 \cdot 10^{-6} \mathrm{~K}^{-1}\left({ }^{\circ} \mathrm{C}^{-1}\right)$.

In the manifestation of glass transition of the test, the sample is calculated coefficient of linear thermal expansion before and after glass transition.

The average coefficient of linear thermal expansion $\bar{\alpha}, \mathrm{K}^{-1}\left({ }^{\circ} \mathrm{C}^{-1}\right)$ in the set temperature range $\mathrm{T}_{1}$ and $\mathrm{T}_{2}$ is calculated using the TMA curve according to the formula: $\bar{\alpha}=\Delta \mathbf{L} / \Delta \mathrm{T} \times \mathbf{1} / \mathbf{L}_{\circ}$; where $\Delta \mathrm{L}-$ change in the length of the test sample within the temperature range, $\mu \mathrm{m} ; \Delta \mathbf{T}=\mathbf{T}_{2}-\mathbf{T}_{1}$; temperature increment from $\mathrm{T}_{1}$ to $\mathrm{T}_{2}, \mathrm{~K}\left({ }^{\circ} \mathrm{C}\right) ; \mathrm{L}_{0}$ - the length of the test sample at $23^{\circ} \mathrm{C}, \mu \mathrm{m}$.

The dependence of Young's modulus and strain under a load of Universal Dentin on temperature was estimated in the three-point bending mode. The loaded sample under the scheme of three-point transverse bending is heated. Then, the sample's resistance force is determined depending on the temperature with further construction of the thermometric curve. The temperature range was between minus $20^{\circ} \mathrm{C}$ and up to plus $70^{\circ} \mathrm{C}$ with a heating rate of $1 \mathrm{~K} / \mathrm{min}$. Force application frequency was $5 \mathrm{~Hz}$, a mechanical force was about $45 \mathrm{~kg} / \mathrm{m}^{2}$, deformation amplitude was about $240 \mu \mathrm{m}$.

Young's Modulus measurement were also performed with penetration carrier. The temperature range was between $-20^{\circ} \mathrm{C}$ and up to $+70^{\circ} \mathrm{C}$ with a heating rate of $1 \mathrm{~K} / \mathrm{min}$. Force application frequency was $0,5 \mathrm{~Hz}$ and $5 \mathrm{~Hz}$, mechanical force was about $1024 \mathrm{~kg} / \mathrm{m}^{2}$, which is roughly equal to the force generated by the biting of human jaws.

For the electron scanning microscopic examination, the JEOL-JSM-6490LV (JEOL Ltd., Tokyo, Japan) scanning electron microscope was used. It was equipped with a low vacuum system that allows the observation of water-saturated or non-conductive samples without spraying.

\section{Data Analysis}

The one-way ANOVA test was provided with StatPlus 6 (AnalystSoft Inc., Walnut, CA, USA) for the average data obtained in each testing group. The significance level was set at $\mathrm{p}<0.05$.

\section{Results}


The analysis of the results revealed that linear thermal expansion coefficient (LTEC) is different between the samples with preliminary thermal processing and the untreated samples. LTEC for dentin nanocomposite samples has the negative values, as well as for the enamel nanocomposite samples. The dentin nanocomposite samples in the studied temperature range after pre-heating and polymerization have higher LTEC after $30^{\circ} \mathrm{C}$ compared to dentin nanocomposite untreated samples (Figure 1). Statistically significant difference was observed at $62^{\circ} \mathrm{C}(\mathrm{p}<0.05)$ and higher temperature.

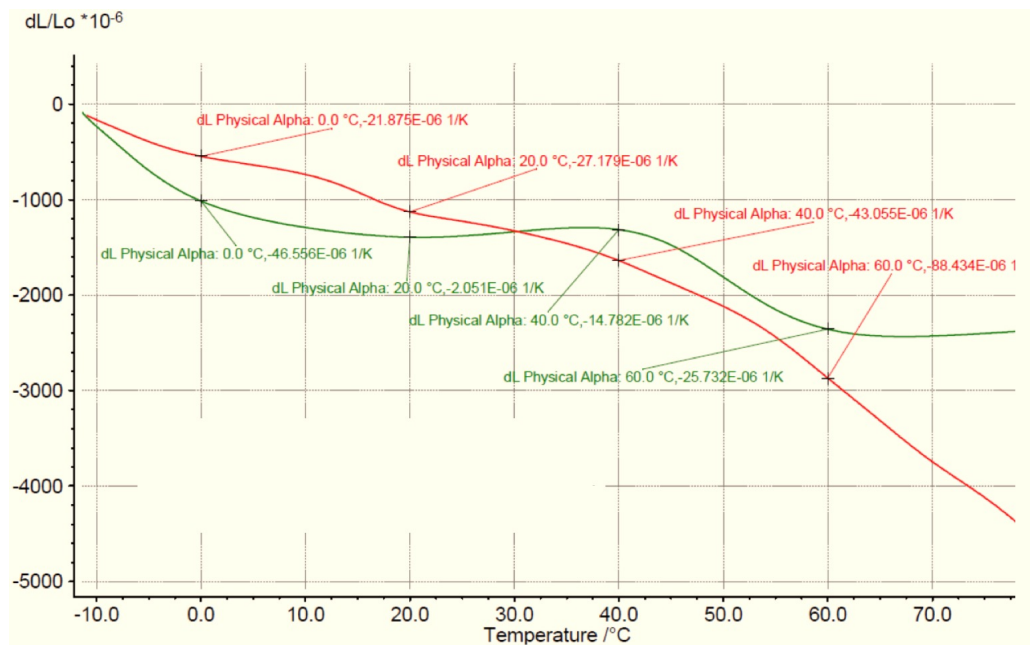

Figure 1. Average linear thermal expansion coefficient for dentin nanocomposite samples. Untreated samples (the red line) and samples after being exposed to $55^{\circ} \mathrm{C}$ (the green line).

LTEC of both types of tested enamel nanocomposite samples have a similar pattern; however, prepolymerization heated samples had a statistically higher LTEC $(\mathrm{p}<0.05)$ at $57^{\circ} \mathrm{C}$ and higher temperature (Figure 2)

Comparing the data regarding depth penetration of enamel nanocomposite untreated samples and enamel nanocomposite samples after $55^{\circ} \mathrm{C}$ exposure $500 \%$ difference was shown for enamel nanocomposite after $55^{\circ} \mathrm{C}$ exposure samples. Thus preparatory thermal exposure process grants 5 times better stress and strain stability for enamel nanocomposite material $(\mathrm{p}<0.01)$.

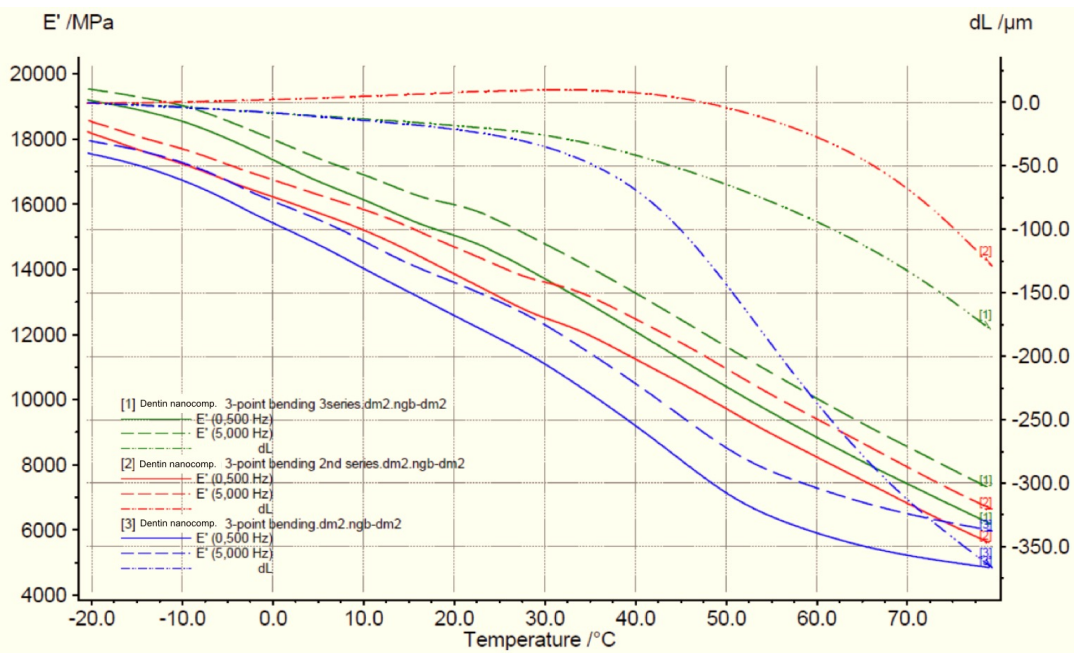

Figure 2. Average linear thermal expansion coefficient for Enamel Nanocomposite Samples. Untreated samples (the pink line) and after being exposed to $55^{\circ} \mathrm{C}$ (the blue line). 
The results of the temperature dependence of Young's modulus are presented in Figures 3 and 4 . It was revealed that Young's modulus of the dentin nanocomposite samples after thermal processing at $55^{\circ} \mathrm{C}$ was higher in total after the first heating cycle by $15 \%$ compared to the untreated dentin nanocomposite samples $(\mathrm{p}<0.05)$. Young's modulus's difference did not exceed $5 \%$ in the second $(\mathrm{p}=0.6)$ and third $(\mathrm{p}=0.6)$ tests.

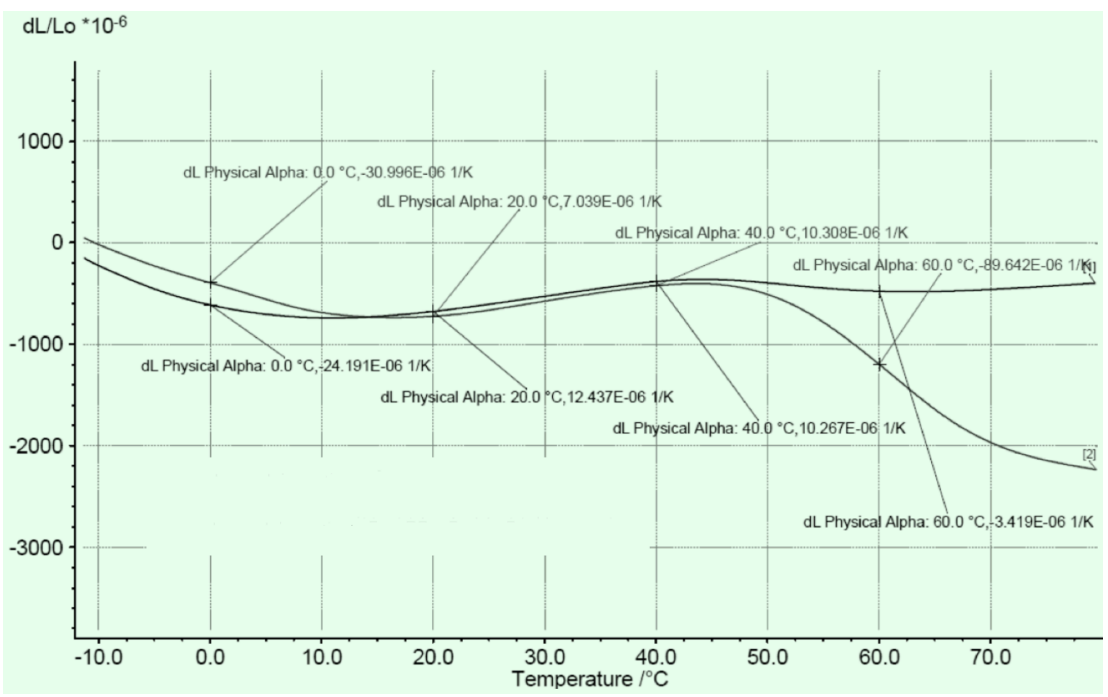

Figure 3. Average Young's modulus measurement in 3-point bending situation. Dentin nanocomposite untreated samples. Three sequential measurements of the same sample.

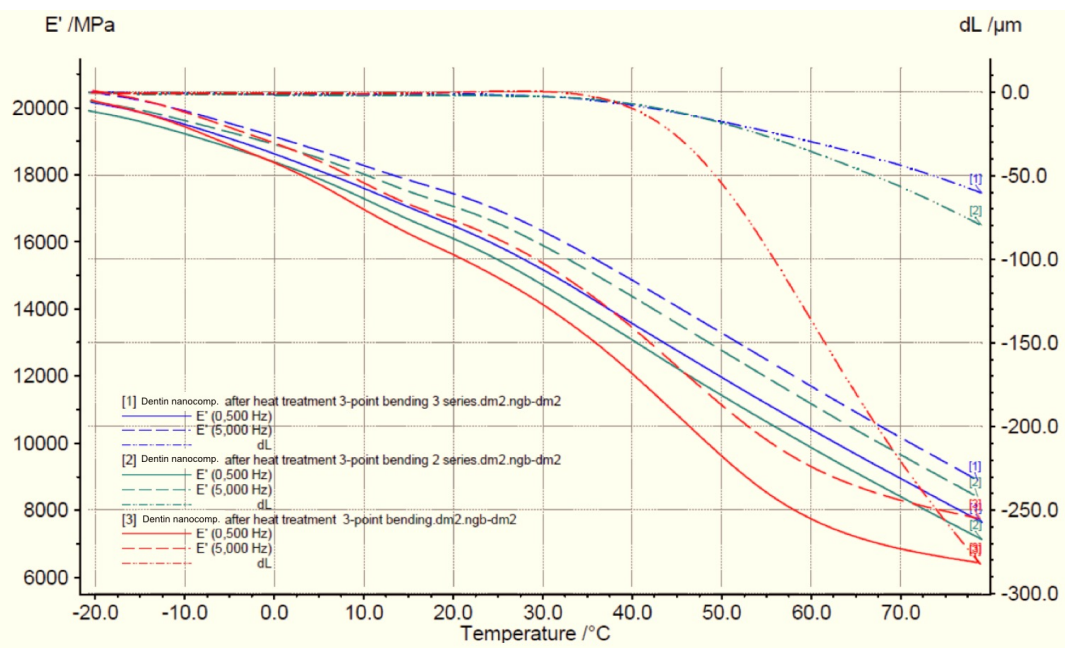

Figure 4. Average young's Modulus measurement in 3-point bending situation. Dentin nanocomposite samples after $55^{\circ} \mathrm{C}$ exposure. Three sequential measurements of the same samples.

During scanning electron microscopy (SEM) of all baseline samples, the microdisperse structure of the materials with particle sizes from 0.5 to 5 microns was observed. The total porosity of the material was $15 \%$ of the total volume, individual pores reached a size of $5 \mu \mathrm{m}$ (Figure 5$)$.

In the study of the structure of pre-heated to polymerization, samples revealed the compaction of the material structure; there are separate isolated pores up to $2 \mu \mathrm{m}$ in size, the volume of total porosity decreased to $5-7 \%(\mathrm{p}<0.05)$ (Figure 6). Electron-scanning photos of samples with pre-polymerization heating are characterized by higher image brightness (Figure 7). 


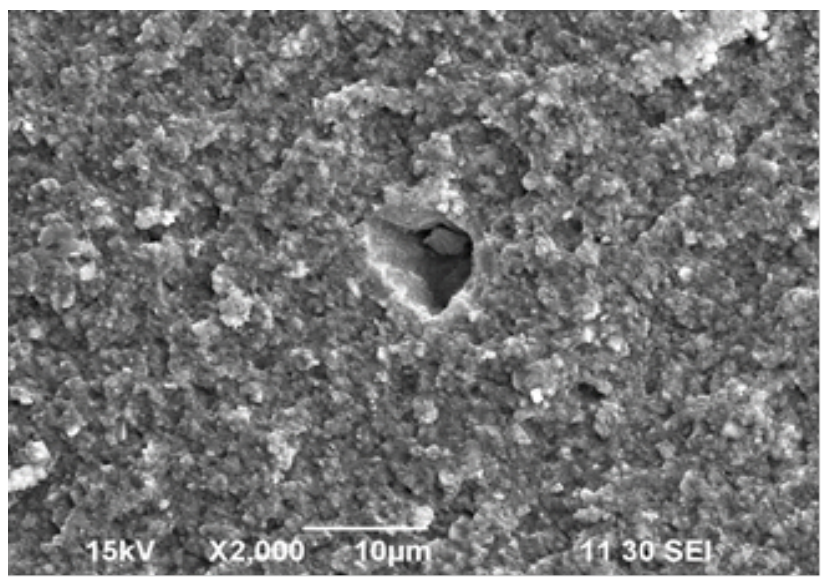

Figure 5. The untreated nanocomposite sample. Pores are clearly distinguished between the crystals, the total porosity of the material reaches $15 \%$, particles 0.5 and 5 microns in size.

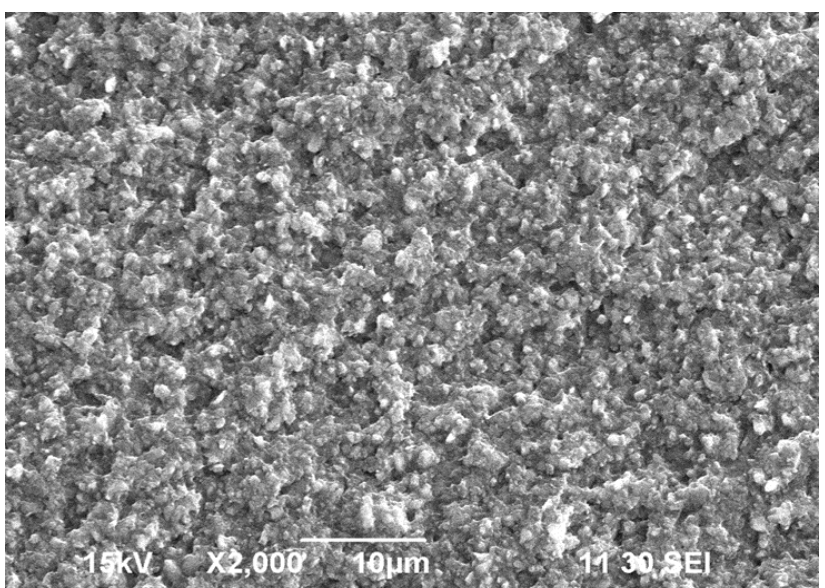

Figure 6. The sample is heated prior to polymerization. It reveals significant compaction of the material structure and a decrease in the total porosity to $5-7 \%$.

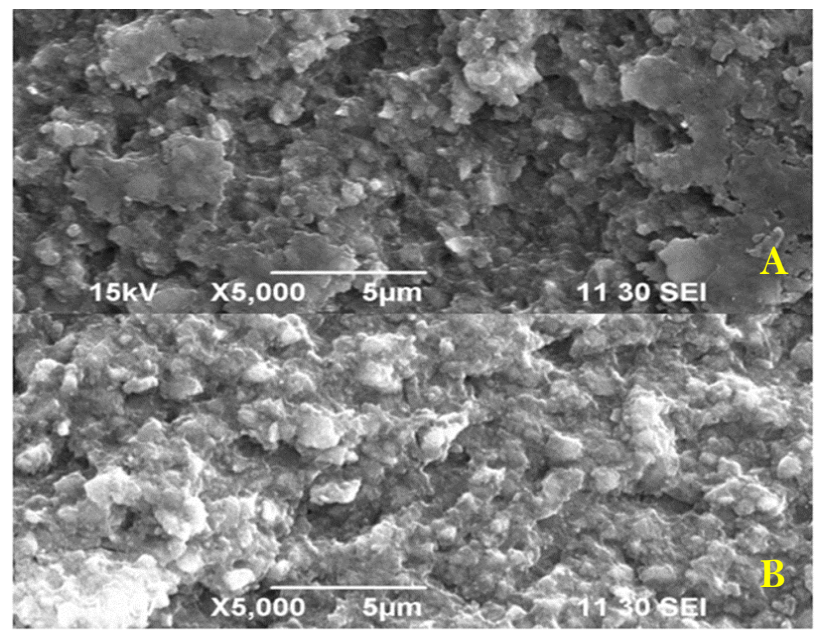

Figure 7. Comparison of SEM samples with the heating (B) and untreated (A) samples: the smoothness of the dispersed structure of the sample subjected to pre-polymerization heating and a decrease in its porosity are clearly observed. A sample with a thermal history has greater image brightness due to a closer arrangement of particles.

\section{Discussion}


The link between dimensional stability and clinical success of resin composites has long been postulated [29-31]. Thermal expansion is the factor that can also affect the dimensional stability of dental resin composites [26]. The differential in the thermal expansion coefficients between dental composite resins and tooth structures lead to differences in movement and the generation of stress on the bonded interface between them. In this study, linear thermal expansion coefficient measurements for all tested samples were performed with a temperature range between minus $10^{\circ} \mathrm{C}$ and up to plus $70^{\circ} \mathrm{C}$ with a heating rate of $1 \mathrm{~K} / \mathrm{min}$ and the difference for all tested samples was statistically more favour for the pre-polymerization heating, that is why the first null-hypothesis was rejected.

Comparing the absolute value of LTEC of the dentin and enamel nanocomposite materials, the enamel nanocomposite was less susceptible to effect of changing size with the pre-heating than the dentin nanocomposite material and the difference was significant after $0^{\circ} \mathrm{C}(\mathrm{p}<0.05)$. Such properties should allow dentin nanocomposite material to have better contact with tooth tissue with no detachment under hot and cold food effects [27,28]. However, it is possible to observe fractures between dentin and enamel nanocomposite materials under thermal impact conditions due to differences in LTEC values for these materials [26].

The results of the study of Young's modulus dependence on temperature confirm the conclusion that the physical properties of the composite material significantly improve after heating [32] that accepts the second null hypothesis. There is an increase in the rate of Young's modulus by $15 \%$ for samples with preliminary pre-polymerization heating. It should also be noted that after second heating-cooling cycles, this effect is eliminated.

Electron scanning microscopy results indicate an increase in the density of the images with samples after pre-polymerization heating, and there is a decrease in the porosity of the material. Increasing the brightness of the image can be judged on the proximity of the filler particles and the degree of their reflection [33]. Thus, the heated material, according to SEM, has a higher density, and therefore a lower roughness due to the greater smoothness of the dispersed structure of the matrix in the composite after the conversion during heating. Such changes in the structure of the composite material have a positive effect on the strength of the restoration and its longevity [34].

\section{Conclusion}

The research results made it possible to detect differences in physical properties among the samples of composite materials that have undergone preliminary thermal processing and untreated before polymerization samples. The material that has passed the preliminary stage of thermal processing at $55^{\circ} \mathrm{C}$ is significantly less deformed under load than the material that does not have thermal processing. The use of pre-heated composite material facilitates its incorporation into the cavity and distribution and increases the restoration's longevity. It is also important that the ability of the material to withstand the compression load is also increased. Preliminary thermal processing increases dentin resistance and enamel nanocomposite to deformation under load up to five times, allowing you to keep the shape of the fillings when chewing load. It is also proved to increase the density of the pre-heated material and reduce its porosity. We have concluded that heating a composite material is a practical and effective way to improve its properties based on the above.

\section{Authors' Contributions}




\begin{tabular}{|c|c|c|}
\hline SA & (D) $0000-0002-4471-2128$ & Methodology, Formal Analysis, Writing - Review and Editing and Resources. \\
\hline YB & (iD) $0000-0002-0179-4717$ & Methodology, Formal Analysis, Writing - Review and Editing and Resources. \\
\hline YB & (iD $0000-0002-3362-9943$ & Investigation and Formal Analysis. \\
\hline DT & -- & Methodology, Formal Analysis, Writing - Review and Editing and Resources. \\
\hline $\mathrm{OM}$ & (D) $0000-0002-9878-7045$ & Conceptualization and Data Curation. \\
\hline AA & (iD) $0000-0002-5586-4805$ & Investigation and Resources. \\
\hline GD & (iD) $0000-0003-3140-4078$ & Investigation. \\
\hline SS & (iD) $0000-0003-1989-4596$ & Project Administration. \\
\hline $\mathrm{SN}$ & (iD) $0000-0003-3651-4516$ & Project Administration. \\
\hline
\end{tabular}

\section{Financial Support}

None.

\section{Conflict of Interest}

The authors declare no conflicts of interest.

\section{References}

[1] Kumari CM, Bhat KM, Bansal R. Evaluation of surface roughness of different restorative composites after polishing using atomic force microscopy. J Conserv Dent 2016; 19(1):56-62. https://doi.org/10.4103/0972-0707.173200

[2] Aytac, F, Karaarslan ES, Agaccioglu M, Tastan E, Buldur M, Kuyucu E. Effects of novel finishing and polishing systems on surface roughness and morphology of nanocomposites. J Esthet Restor Dent 2016; 28(4):247-61. https://doi.org/10.1111/jerd.12215

[3] Lohbauer U, Zinelis S, Rahiotis C, Petschelt A, Eliades G. The effect of resin composite pre-heating on monomer conversion and polymerization shrinkage. Dent Mater 2009; 25(4):514-9. https://doi.org/10.1016/j.dental.2008.10.006

[4] Kaleem M, Satterthwaite JD, Watts DC. A method for assessing force/work parameters for stickiness of unset resincomposites. Dent Mater 2011; 27(8):805-10. https://doi.org/10.1016/j.dental.2011.04.005

[5] Kaleem M, Watts DC. Stiffness of uncured resin-composites assessed via cavity-packing forces. Dent Mater 2016; 32(9):e199-203. https://doi.org/10.1016/j.dental.2016.06.004

[6] Deb S, Di Silvio L, Mackler HE, Millar BJ. Pre-warming of dental composites. Dent Mater 2011; 27(4):e51-9. https://doi.org/10.1016/j.dental.2010.11.009

[7] Blalock JS, Holmes RG, Rueggeberg FA. Effect of temperature on unpolymerized composite resin film thickness. J Prosthet Dent 2006; 96(6):424-32. https://doi.org/10.1016/j.prosdent.2006.09.022

[8] Wagner WC, Aksu MN, Neme AL, Linger JB, Pink FE, Walker S. Effect of pre-heating resin composite on restoration microleakage. Oper Dent 2008; 33(1):72-8. https://doi.org/10.2341/07-41

[9] Lempel E, Öri Z, Szalma J, Lovász BV, Kiss A, Tóth Á, et al. Effect of exposure time and pre-heating on the conversion degree of conventional, bulk-fill, fiber reinforced and polyacid-modified resin composites. Dent Mater 2019; 35(2):217-28. https://doi.org/10.1016/j.dental.2018.11.017

[10] Metalwala Z, Khoshroo K, Rasoulianboroujeni M, Tahriri M, Johnson A, Baeten J, et al. Rheological properties of contemporary nanohybrid dental resin composites: The influence of preheating. Polym Test 2018; 72:157-63. https://doi.org/10.1016/j.polymertesting.2018.10.013

[11] Lovell LG, Newman SM, Bowman CN. The effects of light intensity, temperature, and co-monomer composition on the polymerization behavior of dimethacrylate dental resins. J Dent Res 1999; 78(8):1469-76. https://doi.org/10.1177/00220345990780081301

[12] Lovell LG, Berchtold KA, Elliot JE, Lu H, Bowman CN. Understanding the kinetics and network formation of dimethacrylate dental resins. Polym Adv Technol 2001; 12:335-45. https://doi.org/10.1002/pat.115

[13] Trujillo M, Newman SM, Stansbury JW. Use of near-IR to monitor the influence of external heating on dental composite photopolymerization. Dent Mater 2004; 20(8):766-77. https://doi.org/10.1016/j.dental.2004.02.003

[14] Daronch M, Rueggberg FA, De Goes MF. Monomer conversion of pre-heated composite. J Dent Res 2005; 84(7):663-7. https://doi.org/10.1177/154405910508400716

[15] Daronch M, Rueggeberg FA, De Goes MF, Giudici R. Polymerization kinetics of pre- heated composite. J Dent Res 2006; 85(1):38-43. https://doi.org/10.1177/154405910608500106

[16] Liu J, Li Q, Xu S. Influence of nanoparticles on fluidity and mechanical properties of cement mortar. Constr Build Mater 2015; 101(1):892-901. https://doi.org/10.1016/j.conbuildmat.2015.10.149 
[17] Tauböck TT, Tarle Z, Marovic D, Attin T. Pre-heating of high-viscosity bulk-fill resin composites: effects on shrinkage force and monomer conversion. J Dent 2015; 43(11):1358-64. https://doi.org/10.1016/j.jdent.2015.07.014

[18] Calheiros FC, Daronch M, Rueggeberg FA, Braga RR. Effect of temperature on composite polymerization stress and degree of conversion. Dent Mater 2014; 30(6):613-8. https://doi.org/10.1016/j.dental.2014.02.024

[19] Dionysopoulos D, Papadopoulos C, Koliniotou-Koumpia E. Effect of temperature, curing time, and filler composition on surface microhardness of composite resins. J Conserv Dent 2015; 18(2):114-8. https://doi.org/10.4103/0972-0707.153071

[20] Silva JC, Vieira RR, Rege ICC, Cruz CAS, Vaz LG, Estrela C, et al. Pre-heating mitigates composite degradation. J Appl Oral Sci 2015; 23(6):571-9. https://doi.org/10.1590/1678-775720150284

[21] Soares CJ, Rodrigues MP, Oliveira LRS, Braga SSL, Barcelos LM, Silva GR, et al. An evaluation of the light output from 22 contemporary light curing units. Braz Dent J 2017; 28(3):362-371. https://doi.org/10.1590/0103-6440201601466

[22] International Organization for Standardization. ISO 11359-2:1999. Plastics — Thermomechanical analysis (TMA) Part 2: Determination of coefficient of linear thermal expansion and glass transition temperature.

[23] International Organization for Standardization. ISO 11359-1:1999 Thermomechanical analysis (TMA). Part 1. General principles.

[24] International Organization for Standardization. ISO 6721-11:2012. Plastics — Determination of dynamic mechanical properties - Part 11: Glass transition temperature.

[25] International Organization for Standardization. ISO 11359-3:2002 Plastics. Thermomechanical analysis (TMA). Part 3. Determination of penetration temperature.

[26] Ferracane JL, Hilton TJ, Stansbury JW, Watts DC, Silikas N, Ilie N, et al. Academy of dental materials guidanceresin composites: Part II-Technique sensitivity (handling, polymerization, dimensional changes). Dent Mater 2017; 33(11):1171-91. https://doi.org/10.1016/j.dental.2017.08.188

[27] Jepson NJ, McGill JT, McCabe JF. Influence of dietary simulating solvents on the viscoelasticity of temporary soft lining materials. J Prosthet Dent 2000; 83(1):25-31. https://doi.org/10.1016/s0022-3913(00)70085-0

[28] Gupta SK, Saxena P, Pant VA, Pant AB. Release and toxicity of dental resin composite. Toxicol Int 2012; 19(3):22534. https://doi.org/10.4103/0971-6580.103652

[29] Döbrentey Z. Direct anterior composite restoration - a predictable outcome: case report. Endodontics Today 2019; 17(3):71-4. https://doi.org/10.36377/1683-2981-2019-17-3-71-74

[30] Rondoni D. Composite layered overlay: micro-invasive approach. Endodontics Today 2019; 17(4):67-9. https://doi.org/10.36377/1683-2981-2019-17-4-67-69

[31] Ilie N, Hilton TJ, Heintze SD, Hickel R, Watts DC, Silikas N, et al. Academy of dental materials guidance-resin composites: Part I-Mechanical properties. Dent Mater 2017; 33(8):880-94. https://doi.org/10.1016/j.dental.2017.04.013

[32] Kramer MR, Edelhoff D, Stawarczyk B. Flexural strength of preheated resin composites and bonding properties to glass-ceramic and dentin. Materials 2016; 9(2):83. https://doi.org/10.3390/ma9020083

[33] Navarro JG, Cesar D, Musumeci P, Assmann R, Marchetti B, Marx D. Electron microscopy inspired setup for single-shot 4-d trace space reconstruction of bright electron beams. 9th International Particle Accelerator Conference, Vancouver, BC, Canada. 2018; 4911-2. https://doi.org/10.18429/JACoW-IPAC2018-THPML106

[34] Randolph LD, Palin WM, Leloup G, Leprince JG. Filler characteristics of modern dental resin composites and their influence on physico-mechanical properties. Dent Mater 2016; 32(12):1586-99. https://doi.org/10.1016/j.dental.2016.09.034 